\title{
Diet of Hemigrammus marginatus (Characiformes: Characidae) in the Upper Contas River, Diamantina Plateau (Bahia, Brazil)
}

\author{
Silvia B. Barreto' (D), André T. Silva² (D), Fabiane B. Souza³ (D) \& Ricardo Jucá-Chagas² (D)
}

\begin{abstract}
1. Instituto de Biologia, Universidade Federal da Bahia, Rua Barão de Jeremoabo, 147, Ondina, 40170-115 Salvador, BA, Brazil (sbrittob@gmail.com)
2. Departamento de Ciências Biológicas, Universidade Estadual do Sudoeste da Bahia, Av. José Moreira Sobrinho, s/n, Jequiezinho, 45206-190 Jequié, BA, Brazil (silva.at@gmail.com; rjchagas@hotmail.com)

3. Departamento de Ciências Biológicas, Universidade Estadual de Feira de Santana, Av. Transnordestina, s/n, Novo Horizonte, 44036-900 Feira de Santana, BA, Brazil (fabiane-barreto@hotmail.com)
\end{abstract}

Received 23 March 2018

Accepted 09 October 2018

Published 29 November 2018

$10.1590 / 1678-4766 \mathrm{e} 2018036$

\begin{abstract}
Studies on the composition of fish diet and on how species exploit food resources are especially relevant in tropical freshwater systems, where dietary plasticity is a commonly used strategy. In this study, we analysed the food spectrum and the environmental, seasonal and ontogenetic variations in the diet of a characid species [Hemigrammus marginatus Ellis, 1911 (Characidae)] in the region of the Upper Contas River, in the Diamantina Plateau, Brazil. We verified an omnivorous/invertivorous and opportunistic food habit, with predominance of insects and microcrustaceans, followed by filamentous algae. Seasonality did not alter the food resources used by the species. However, differences were detected in the dominant categories when comparing the two sampled rivers, as well as in the food consumption throughout the development of the species. These data increase the knowledge about the biology of H. marginatus and allow understanding the influence of the characteristics of the rivers and their surroundings in the trophic ecology of the species, as our findings have shown that, although insects have been expressive in both studied localities, microcrustaceans exhibit a greater relative importance in the more lentic environment, which is probably related to the variation in the availability of these resources in the environment.
\end{abstract}

KEYWORDS. Feeding, coastal drainage, trophic ecology, freshwater fishes.

RESUMO. Dieta de Hemigrammus marginatus (Characiformes: Characidae) no Alto Rio de Contas, Chapada Diamantina (Bahia, Brasil). Estudos sobre a composição da dieta de peixes e de como as espécies exploram os recursos alimentares são especialmente relevantes em sistemas de água doce tropicais, onde a plasticidade alimentar é uma estratégia comumente utilizada. Neste trabalho, analisamos o espectro alimentar e as variações ambientais, sazonais e ontogenéticas na dieta de uma espécie de caracídeo [Hemigrammus marginatus Ellis, 1911 (Characidae)] na região do Alto Rio de Contas, na Chapada Diamantina, Brasil. Verificamos um hábito alimentar onívoro/invertívoro e oportunista, com predominância de insetos e microcrustáceos, seguido de algas filamentosas. A sazonalidade não alterou os recursos alimentares utilizados pela espécie. No entanto, foram detectadas diferenças nas categorias dominantes ao comparar os dois rios amostrados, bem como no consumo do alimento ao longo do desenvolvimento da espécie. Esses dados ampliam o conhecimento acerca da biologia de H. marginatus e permitem entender a influência das características dos rios e de seus entornos na ecologia trófica da espécie, visto que, embora o item insetos tenha sido expressivo em ambos os locais estudados, microcrustáceos exibiram maior importância relativa no ambiente mais lêntico, o que possivelmente está relacionado à variação na disponibilidade destes recursos no ambiente.

PALAVRAS-CHAVE. Alimentação, drenagem costeira, ecologia trófica, peixes de água doce.

Neotropical freshwater fishes, in general, present trophic plasticity, varying their diet according to space, time and ontogeny (ABELHa et al., 2001). This lack of specialization allows the use of the most variable food items available in the environment, favouring the sharing of resources among the members of the community as well as reduction of the intra- and interspecific competition for food (Lowe-McConnell, 1999; ARAúJo et al., 2005; Mise et al., 2013). The items used as food resource by the fish are quite diverse, differing in type (animal, plant or detritus/ sediment) and origin (autochthonous or allochthonous), and their availability in the aquatic environments is also variable (Bennemann et al., 2005). This variation is influenced by the characteristics of the water body and its surrounding and can occur seasonally and/or spatially, mainly as a function of the longitudinal gradient of the watercourse (VANNOTE et al., 1980; Esteves \& Aranha, 1999; Gomiero \& BraGa, 2005).

In this context, the structure of the riparian vegetation can directly and indirectly influence the availability of food resources to the fishes, since many species consume items from the adjacent terrestrial environment, such as detritus, fruits, leaves, invertebrates and, although uncommon, small vertebrates (SABINO \& CASTRO, 1990; ABELHA et al., 2001; Esteves \& Lobón-Cerviá, 2001; Souza et al., 2015). Moreover, even if not consumed directly, the allochthonous material corresponds to the nutritional base of several autochthonous aquatic organisms (e.g. detritivores aquatic invertebrates), which represent an important food source for several fish species in freshwater environments (UIEDA et al., 1997; GOMIERO \& BraGa, 2008). 
Due to their importance in the energy flow and nutrient cycling, small-sized fishes represent an indispensable link in the trophic chain of aquatic environments (LowEMCCONNELL, 1999; CoRrÊA et al., 2009; FIORI et al., 2016). Among these species, there is Hemigrammus marginatus Ellis 1911, a small characid widely distributed in the Neotropical region, occurring in the basins of Guaporé, Orinoco, Amazonas, Paraná, Paraguai, and São Francisco rivers, as well as in some rivers of the Brazilian Northeast (e.g. Jaguaribe, Itapicuru, Paraguaçu, and Contas rivers) (BUCKUP et al., 2007; EsCHMEYER et al., 2018). Hemigrammus marginatus dwells in large shoals (30 to 50 individuals, according to CASATTI et al., 2003), exploits the middle of the water column, and mainly consumes food items carried by the current, preferentially inhabiting margin environments (both lentic and lotic) in association with aquatic macrophytes (Grant \& NoAKes, 1987; CASATti et al., 2003; CripPa et al., 2009; Brandão-Gonçalves et al., 2010; Ceneviva-Bastos et al., 2010).

The Contas River basin, where Hemigrammus marginatus is widely spread, is a coastal hydrographic system that occupies an area of $55,483 \mathrm{~km}^{2}$ in the southcentral region of the Bahia state, Brazil, and belongs to the Northeastern Mata Atlântica freshwater ecoregion (ABELL et al., 2008). This basin can be subdivided into three regions with well-differentiated characteristics: upper, medium and lower Contas (SRHSH, 1993), and H. marginatus has been recorded in these three portions of the basin (André Teixeira da Silva, pers. com.). This study has as sampling area the upper course of the Contas River, in the Diamantina Plateau, where the climatic and physiographic characteristics of the Bahia semi-arid region predominate (Juncá et al., 2005). This area is notable for sheltering several endemic species, such as Hyphessobrycon brumado Zanata \& Camelier 2010, Trichomycterus tete Barbosa \& Costa 2011, a probable new species of Nematocharax (BARRETO et al., 2016), and Hasemania piatan Zanata \& Serra 2010, being the latter considered endangered due to anthropic impacts (SILVA et al., 2016).

To date, there are no data about the feeding or any other aspect of the biology of Hemigrammus marginatus in the Contas River basin. In addition, Hortal et al. (2015) highlight that the knowledge gaps on the ecological characteristics of the species (functional traits, abiotic niches and biotic interactions) have restricted the elaboration of models that adequately describe the biodiversity worldwide. In view of this, we analysed the diet of H. marginatus in two water bodies belonging to the drainage of the Upper Contas River in order to determine its food spectrum and verify the variations in the diet of this species in function of the environments, seasons, and along the ontogeny.

\section{MATERIAL AND METHODS}

Study area. The specimens of Hemigrammus marginatus (Fig. 1) were captured in two rivers: Contas River (133 '58.53"S / 41 $\left.36^{\circ} 7.29^{\prime \prime} \mathrm{W}\right)$ and Água Suja
River (1324'34.79'S / 41'38'1.28'W) (Fig. 2), one of its tributaries. These rivers differ in limnological characteristics and degradation level (Fig. 3). In the Contas River, a section dammed by a bridge in an intermittent region of the river was sampled, representing a lentic environment, being possible to observe the use of its surrounding by cattle and degraded marginal vegetation. In turn, the Água Suja River is a perennial drainage with running water and constitutes therefore a lotic environment. It also has a lower eutrophication level and its riparian vegetation is better preserved.

Fish sampling and analysis. The collections of the Hemigrammus marginatus specimens in the two aforementioned rivers were performed in July 2012 (campaign 1; dry season) and March 2013 (campaign 2; rainy season). The specimens were captured during the day and near the margins of the water bodies using trawl nets. Still in the field, the individuals were placed in plastic bags, duly labelled and fixed in formalin 5\% for the preservation of the stomach content, and later transported to the Universidade Estadual do Sudoeste da Bahia (UESB), campus of Jequié.

In the laboratory, the fish were transferred to flasks containing a $70 \%$ ethanol solution. The standard length $(\mathrm{mm})$ of each specimen was determined using a pachymeter, and

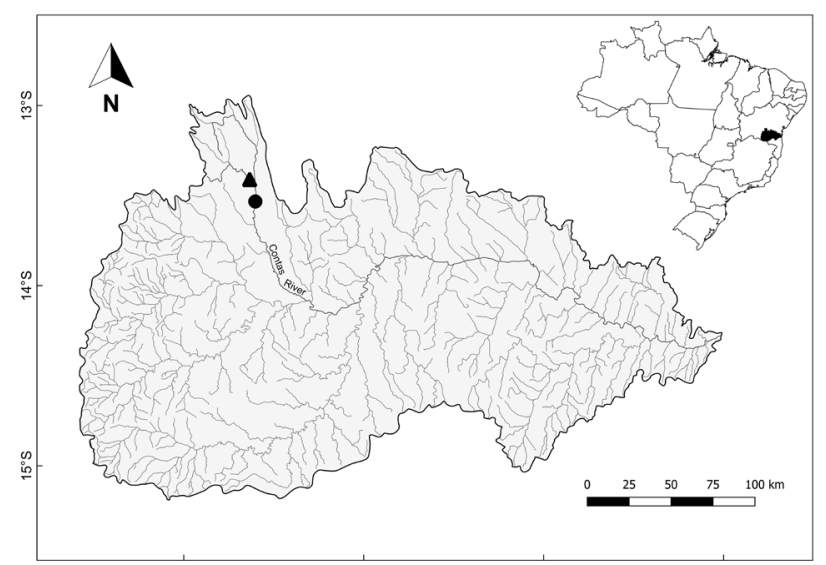

Fig. 1. Map of the Contas River basin, in the south-centre region of the Bahia state (Brazil), with its main drainages and indication of the two collection sites: Contas River (circle) and Água Suja River (triangle).

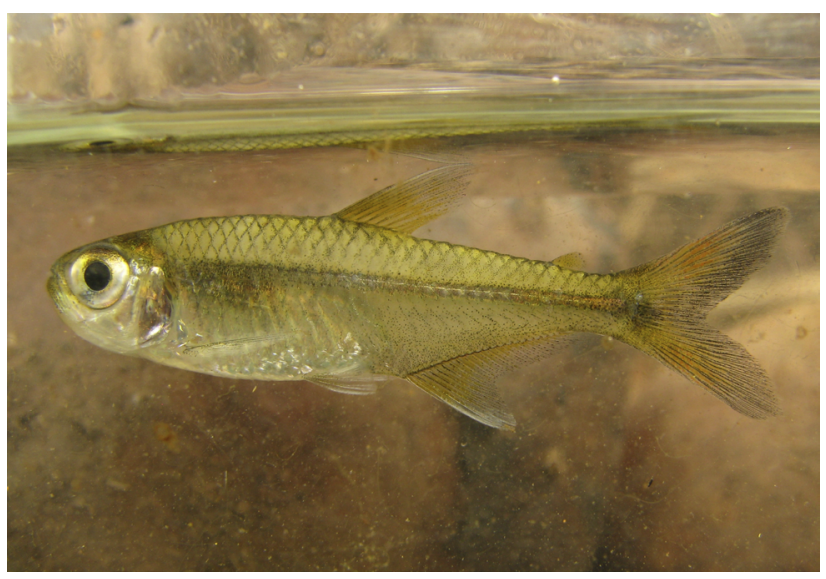

Fig. 2. Living specimen of Hemigrammus marginatus Ellis, 1911 collected during the study (standard length $=32 \mathrm{~mm}$ ). 
the total weight $(\mathrm{g})$ was measured with an analytical balance. After the abdominal incision under stereomicroscope, the stomach of each specimen was removed. The duly identified stomachs with food were placed in flasks containing a $70 \%$ ethanol solution for further analysis.

Data analysis. The stomach contents were observed under stereomicroscope and the food items were identified with the aid of specialized literature (e.g. Borror et al., 1989; RUPPERT et al., 2005; BrusCA \& BrusCa, 2007; MugNaI et al., 2010), and then distributed in nine food categories (Tab. I). These data were distinguished according to the environments (Contas and Água Suja rivers), campaigns (dry and rainy seasons), and length classes (classes 1, 2 and 3 ) in order to verify if the diet of the species differs between lentic and lotic waters, seasons, and along the ontogeny. The length classes were established based on the variation of the standard length of the specimens, using an interval of $9 \mathrm{~mm}$, as follows: $9.5 \mid-18.5$ (class 1$), 18.5 \mid-27.5$ (class 2 ) and $27.5 \mid-36.5$ (class 3 ).

The most representative food categories in the general diet of the species and for each aforementioned condition were determined based on the methods of Frequency of Occurrence (F\%), Dominance (D\%) (Frost \& Went, 1940), and Feeding Index (IAi) (KAWAKAMI \& VAZZOLER, 1980) with modification, since the volumetric values were substituted by the $\mathrm{D} \%$. Furthermore, the dietary data for each environment, campaign, and length class were ordered by a Non-Metric Multidimensional Scaling (NMDS) analysis based on the IAi values of the food categories, and using the Bray-Curtis Index as distance measure (MAGURRAN, 2004).

\section{RESULTS}

From the analysis of the stomach content of 338 specimens of Hemigrammus marginatus, 183 of which were captured in the Contas River and 155 in the Água Suja River, we verified the consumption of a wide variety of food items (Tab. I). Tables II and III present the values of $\mathrm{F} \%, \mathrm{D} \%$ and IAi of the food categories identified in the diet of specimens from the Contas and Água Suja rivers,
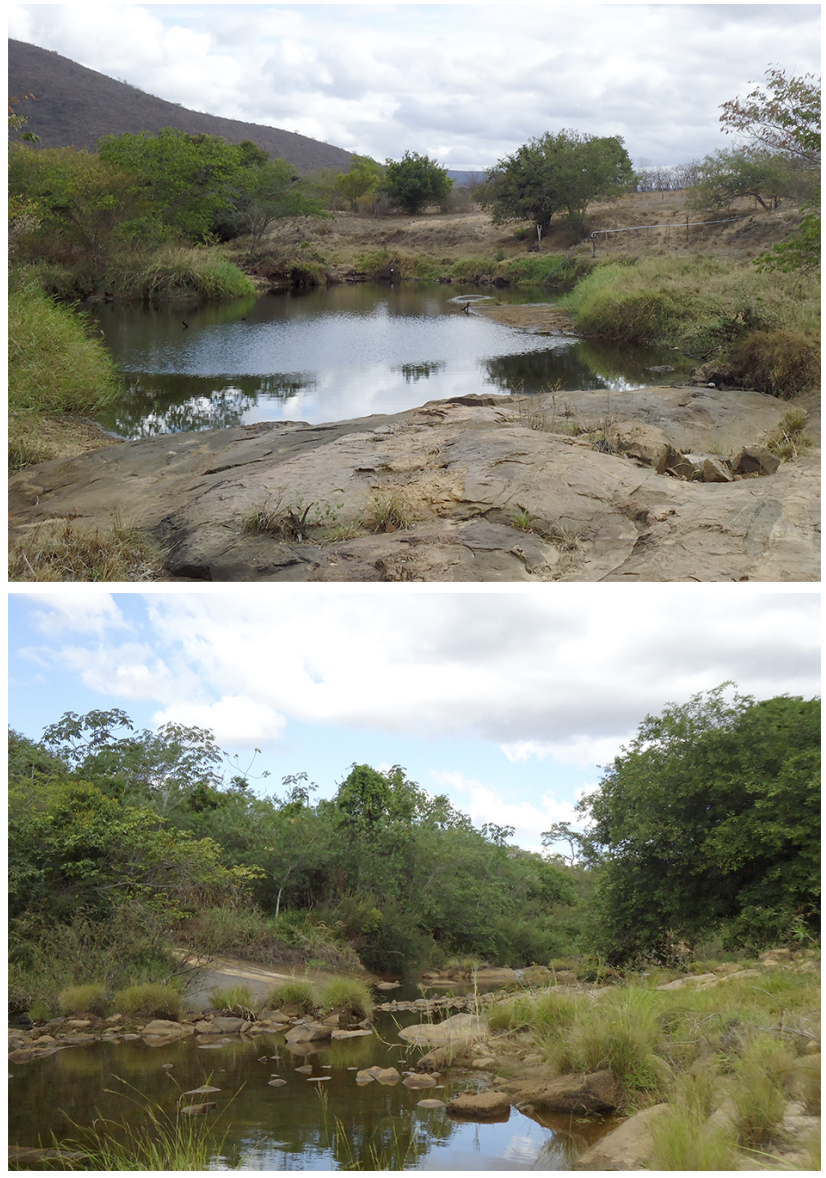

Fig. 3. Collection sites of Hemigrammus marginatus Ellis, 1911 in the Upper Contas River basin: Contas River (above) and Água Suja River (below).

respectively. In general, the predominant categories were microcrustaceans, insects and, secondarily, filamentous algae. Detritus was a representative item in some stomachs only, while the other categories were considered occasional or accidental, since they occurred in a smaller number of stomachs and were not dominant in any of them.

When comparing the two sampled rivers (Fig. 4), we observed that different food categories predominated in the diet of the species. In the Contas River, there was a considerable consumption of insects and microcrustaceans,

Tab. I. Food categories in which the items found in the stomachs of specimens of Hemigrammus marginatus Ellis, 1911 in drainages of the Upper Contas River, Diamantina Plateau, Brazil, were classified.

\begin{tabular}{|c|c|}
\hline Food categories & Description \\
\hline Microcrustaceans & Cladocera, Ostracoda and Copepoda \\
\hline Insects & $\begin{array}{l}\text { Ephemeroptera nymph, Plecoptera nymph, Diptera larva, Diptera pupa, Trichoptera } \\
\text { larva, Trichoptera cocoon, Coleoptera larva, fragments of autochthonous insects, } \\
\text { Coleoptera, Hemiptera, Hymenoptera, Diptera, and fragments of allochthonous insects }\end{array}$ \\
\hline Plant fragment & Plant material and seeds \\
\hline \multicolumn{2}{|l|}{ Unicellular algae } \\
\hline \multicolumn{2}{|l|}{ Filamentous algae } \\
\hline Detritus & Organic particulate matter \\
\hline Sediment & Mineral particles (materials from the bottom of the river, such as grains of sand) \\
\hline Non identified material (NIM) & Unspecified material (animal or plant) \\
\hline Other invertebrates & Spiders, mites, nematodes, and Thecamoeba \\
\hline
\end{tabular}


Tab. II. Frequency of occurrence (F\%), Dominance (D\%), and Feeding Index (IAi) of the food categories in the diet of Hemigrammus marginatus Ellis, 1911 in the Contas River, Diamantina Plateau, Brazil, between campaigns (Campaign 1 and Campaign 2) and among length classes (C1, C2 and C3).

\begin{tabular}{|c|c|c|c|c|c|c|c|c|c|c|c|c|c|c|c|}
\hline & \multicolumn{9}{|c|}{ Campaign 1 (dry season) } & \multicolumn{6}{|c|}{ Campaign 2 (rainy season) } \\
\hline \multirow{3}{*}{ Stomachs analysed } & \multicolumn{3}{|c|}{$\mathrm{C} 1$} & \multicolumn{3}{|c|}{$\mathrm{C} 2$} & \multicolumn{3}{|c|}{$\mathrm{C} 3$} & \multicolumn{3}{|c|}{$\mathrm{C} 2$} & \multicolumn{3}{|c|}{$\mathrm{C} 3$} \\
\hline & & 40 & & & 40 & & & 23 & & & 40 & & & 40 & \\
\hline & $\mathrm{F} \%$ & $\mathrm{D} \%$ & IAi & $\mathrm{F} \%$ & $\mathrm{D} \%$ & IAi & $\mathrm{F} \%$ & $\mathrm{D} \%$ & IAi & $\mathrm{F} \%$ & $\mathrm{D} \%$ & IAi & $\mathrm{F} \%$ & $\mathrm{D} \%$ & IA $\mathrm{i}$ \\
\hline Microcrustaceans & 100.0 & 40.0 & 0.49 & 92.5 & 33.8 & 0.41 & 91.3 & 8.7 & 0.09 & 65.0 & 27.5 & 0.27 & 87.5 & 61.3 & 0.71 \\
\hline Insects & 75.0 & 50.0 & 0.46 & 90.0 & 38.8 & 0.46 & 100.0 & 73.9 & 0.86 & 90.0 & 40.0 & 0.54 & 82.5 & 23.8 & 0.26 \\
\hline Plant fragment & 0.0 & 0.0 & 0.0 & 2.5 & 0.0 & 0.0 & 8.7 & 0.0 & 0.0 & 37.5 & 6.3 & 0.03 & 27.5 & 5.0 & 0.02 \\
\hline Unicellular algae & 10.0 & 0.0 & 0.0 & 32.5 & 0.0 & 0.0 & 4.3 & 0.0 & 0.0 & 20.0 & 0.0 & 0.00 & 12.5 & 0.0 & 0.0 \\
\hline Filamentous algae & 2.5 & 0.0 & 0.0 & 42.5 & 10.0 & 0.06 & 17.4 & 4.3 & 0.01 & 45.0 & 17.5 & 0.12 & 10.0 & 6.3 & 0.01 \\
\hline Detritus & 5.0 & 0.0 & 0.0 & 20.0 & 2.5 & 0.01 & 17.4 & 4.3 & 0.01 & 47.5 & 5.0 & 0.03 & 17.5 & 0.0 & 0.0 \\
\hline Sediment & 2.5 & 0.0 & 0.0 & 15.0 & 0.0 & 0.0 & 0.0 & 0.0 & 0.0 & 5.0 & 0.0 & 0.00 & 7.5 & 0.0 & 0.0 \\
\hline $\begin{array}{c}\text { Non identified } \\
\text { material }\end{array}$ & 35.0 & 10.0 & 0.05 & 35.0 & 15.0 & 0.06 & 39.1 & 4.3 & 0.02 & 2.5 & 2.5 & 0.00 & 2.5 & 2.5 & 0.0 \\
\hline Other invertebrates & 15.0 & 0.0 & 0.0 & 7.5 & 0.0 & 0.0 & 13.0 & 4.3 & 0.01 & 27.5 & 1.3 & 0.01 & 32.5 & 1.3 & 0.01 \\
\hline
\end{tabular}

Tab. III. Frequency of occurrence (F\%), Dominance (D\%), and Feeding Index (IAi) of the food categories in the diet of Hemigrammus marginatus Ellis, 1911 in the Água Suja River, Diamantina Plateau, Brazil, between campaigns (Campaign 1 and Campaign 2) and among length classes (C1, C2 and C3).

\begin{tabular}{|c|c|c|c|c|c|c|c|c|c|c|c|c|c|c|c|c|c|c|}
\hline \multirow{4}{*}{ Stomachs analysed } & \multicolumn{9}{|c|}{ Campaign 1 (dry season) } & \multicolumn{9}{|c|}{ Campaign 2 (rainy season) } \\
\hline & \multicolumn{3}{|c|}{$\mathrm{C} 1$} & \multicolumn{3}{|c|}{$\mathrm{C} 2$} & \multicolumn{3}{|c|}{$\mathrm{C} 3$} & \multicolumn{3}{|c|}{$\mathrm{C} 1$} & \multicolumn{3}{|c|}{$\mathrm{C} 2$} & \multicolumn{3}{|c|}{$\mathrm{C} 3$} \\
\hline & & 5 & & & 39 & & & 26 & & & 3 & & & 43 & & & 39 & \\
\hline & $\mathrm{F} \%$ & $\mathrm{D} \%$ & IAi & $\mathrm{F} \%$ & $\mathrm{D} \%$ & IAi & $\mathrm{F} \%$ & $\mathrm{D} \%$ & IAi & $\mathrm{F} \%$ & $\mathrm{D} \%$ & IA $\mathrm{i}$ & $\mathrm{F} \%$ & $\mathrm{D} \%$ & IAi & $\mathrm{F} \%$ & $\mathrm{D} \%$ & IAi \\
\hline Microcrustaceans & 80.0 & 0.0 & 0.00 & 92.3 & 0.0 & 0.00 & 73.1 & 0.0 & 0.00 & 100.0 & 0.0 & 0.00 & 69.8 & 0.0 & 0.00 & 41.0 & 0.0 & 0.00 \\
\hline Insects & 100.0 & 100.0 & 1.00 & 100.0 & 78.2 & 0.92 & 100.0 & 40.4 & 0.46 & 100.0 & 83.3 & 0.83 & 100.0 & 86.0 & 0.95 & 100.0 & 89.7 & 0.97 \\
\hline Plant fragment & 0.0 & 0.0 & 0.00 & 10.3 & 0.0 & 0.0 & 23.1 & 0.0 & 0.00 & 0.0 & 0.0 & 0.00 & 9.3 & 4.7 & 0.00 & 25.6 & 7.7 & 0.02 \\
\hline Unicellular algae & 20.0 & 0.0 & 0.00 & 48.7 & 2.6 & 0.01 & 7.7 & 0.0 & 0.00 & 33.3 & 0.0 & 0.00 & 14.0 & 0.0 & 0.00 & 2.6 & 0.0 & 0.00 \\
\hline Filamentous algae & 0.0 & 0.0 & 0.00 & 30.8 & 19.2 & 0.07 & 80.8 & 59.6 & 0.54 & 0.0 & 0.0 & 0.00 & 2.3 & 1.2 & 0.00 & 0.0 & 0.0 & 0.00 \\
\hline Detritus & 0.0 & 0.0 & 0.00 & 12.8 & 0.0 & 0.00 & 53.8 & 0.0 & 0.00 & 100.0 & 16.7 & 0.17 & 51.2 & 8.1 & 0.05 & 48.7 & 2.6 & 0.01 \\
\hline Sediment & 20.0 & 0.0 & 0.00 & 28.2 & 0.0 & 0.00 & 46.2 & 0.0 & 0.00 & 100.0 & 0.0 & 0.00 & 37.2 & 0.0 & 0.00 & 35.9 & 0.0 & 0.00 \\
\hline $\begin{array}{c}\text { Non identified } \\
\text { material }\end{array}$ & 0.0 & 0.0 & 0.00 & 10.3 & 0.0 & 0.00 & 11.5 & 0.0 & 0.00 & 0.0 & 0.0 & 0.00 & 2.3 & 0.0 & 0.00 & 2.6 & 0.0 & 0.00 \\
\hline Other invertebrates & 80.0 & 0.0 & 0.00 & 48.7 & 0.0 & 0.00 & 30.8 & 0.0 & 0.00 & 33.3 & 0.0 & 0.00 & 46.5 & 0.0 & 0.00 & 33.3 & 0.0 & 0.00 \\
\hline
\end{tabular}

followed by filamentous algae. In the Água Suja River, there was a predominance of insects, followed by filamentous algae and detritus. Regarding the campaigns (dry and rainy seasons), no differences were detected in the dominant categories. In the Contas River, insects and microcrustaceans predominated in both seasons. On the other hand, in the Água Suja River, insects predominated in both seasons, and a considerable consumption of filamentous algae in the dry season and detritus in the rainy season was also observed.

The three length classes in the Contas River consumed predominantly categories of animal origin (microcrustaceans and insects), and no individual belonging to the class 1 was sampled in the rainy season (Fig. 4). In the Água Suja River, the diet of $H$. marginatus was constituted predominantly by insects, but caveats should be made for class 3 in the dry season, due to a greater consumption of filamentous algae if compared with the other items.

\section{DISCUSSION}

Our analyses allowed the identification of a varied food spectrum for Hemigrammus marginatus of the Upper Contas River, with a diet based on autochthonous items mainly of animal origin, besides algae, detritus and sediment, so that the species, in general, was characterized as omnivorous/ invertivorous and opportunistic. The occurrence of a flexible diet is an important strategy in variable environments such as the locality of the Contas River, since it allows the species to change the type of food consumed when oscillations occur in the relative abundance of resources or when the preferred item is in small supply (KNÖPPEL, 1970; ABELHA et al., 2001). In the present case, the fact that some populations of $H$. marginatus inhabit intermittent drainages with large variation in limnological parameters and resource availability highlights the importance of this feeding strategy to the species. 


\section{SIZE CATEGORIES}

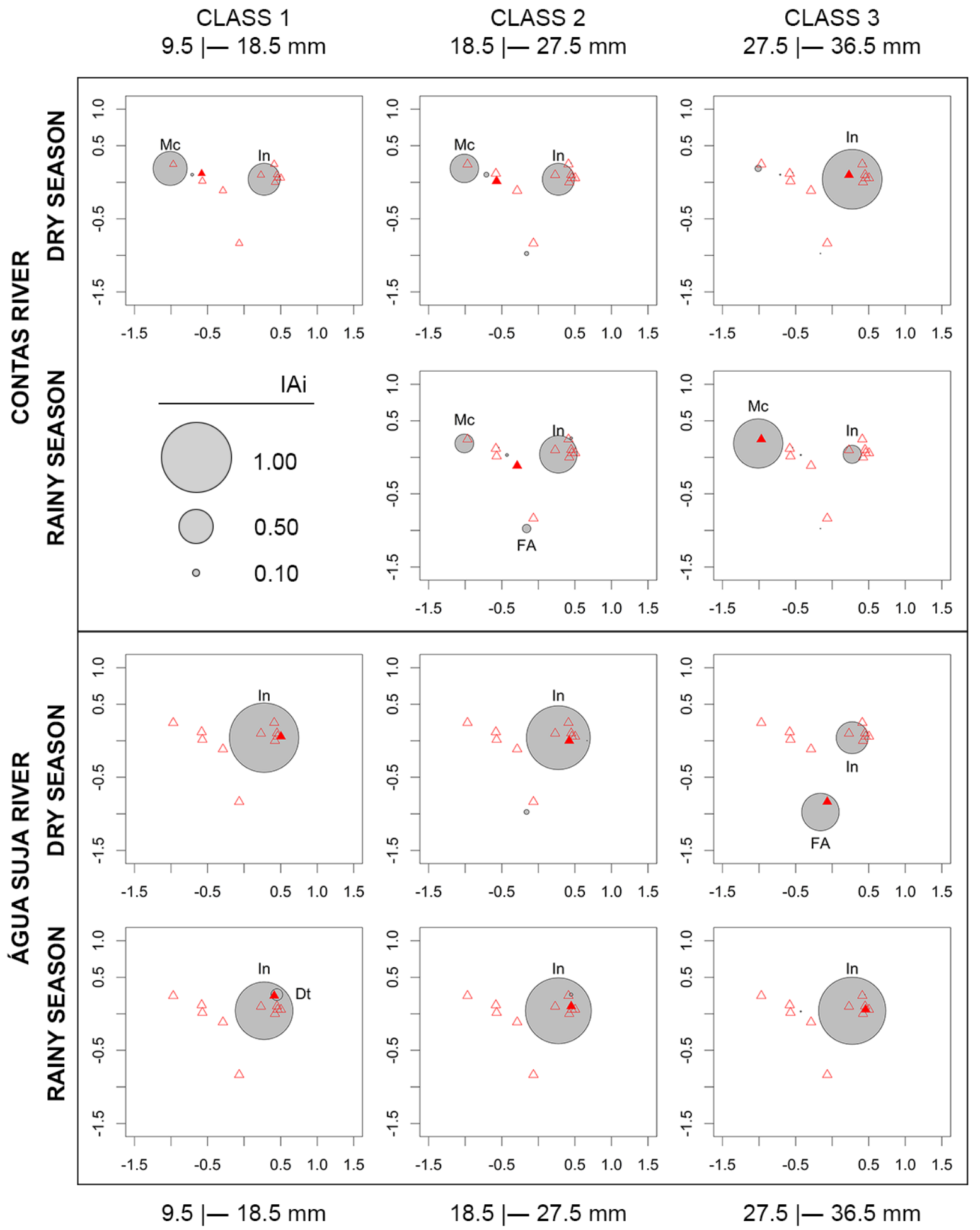

SIZE CATEGORIES

Fig. 4. Plots of the first two axes resulting from the Non-Metric Multidimensional Scaling (NMDS) ordination of individuals of Hemigrammus marginatus Ellis, 1911 from drainages of the Upper Contas River, Diamantina Plateau, Brazil, based on the Feeding Index (IAi) of the food categories consumed. The triangles correspond to the groups of individuals according to collection sites (Contas and Água Suja rivers), campaigns (dry and rainy seasons), and length classes (classes 1, 2 and 3), and the circles correspond to the food categories. For each graph, the respective fish group was highlighted as a filled triangle and the diameter of the circles is proportional to the IAi values observed for each food category (Mc, microcrustaceans; In, insects; FA, filamentous algae; Dt, detritus). 
Regarding studies in lentic systems such as the locality in the Contas River, microcrustaceans represent a significant component of the species' diet (see CASATTI et al., 2003; Pelicice \& Agostinho, 2006). In fact, environments with lentic characteristics, mainly in the marginal regions, favour the development of the zooplankton community (EsTEVES, 1988; Russo \& HaHn, 2006). On the other hand, for the H. marginatus population from the Água Suja River, an environment with lotic characteristics, the category insects resulted in the greatest importance, a fact that was also observed in the Franco stream, Mato Grosso do Sul state (BRANDÃo-GONÇALVES et al., 2010), and in a preserved stream of the Atlantic Forest in São Paulo state (Fragoso-Moura et al., 2017). In the Água Suja River, the better conservation state of the marginal vegetation can be responsible for the considerable contribution of allochthonous material for the water body (Afonso et al., 2000). This material could be used directly or indirectly as food resource by the fish. In the latter case, the fish may consume organisms that are part of the detritivore food chain, as many aquatic insects (ANGERMEIER \& KARR, 1983; PUSEY \& ARTHINGTON, 2003).

In the Água Suja River, the filamentous algae were also important in the diet of the species. This can be related to the greater availability of light and nutrients favouring the development of algae (PUSEY \& ARTHINGTON, 2003). Since the Água Suja River presents a lower depth and a more transparent water, it possibly provided an increase of this food item in this locality, increasing in this way the availability of this resource to the fishes. Thus, the variation found in the diet of $H$. marginatus can be related to the different environmental conditions and availability of resources in the different locations, which reflects the opportunistic character of the species.

Despite of being described as a species sensitive to the consequences of the degradation of the marginal vegetation (TERESA \& CASATTI, 2010), the survival of H. marginatus in an altered environment such as the Contas River can be related to its capacity to consume the various food resources available in the locality. Another factor that can be related to this dietary plasticity is the possibility that $H$. marginatus corresponds to a species complex and therefore the populations from the Paraná River basin represent a taxonomic unit distinct from the populations from other basins (ОтА et al., 2015). However, this issue has not yet been properly revised and $H$. marginatus remains as the only valid taxonomic nomenclature for these fish (EsCHMEYER et al., 2018).

Variation between different environments in the diet of $H$. marginatus was also verified between two floodplain lakes of the Upper Paraná River, where the species ingested as main item detritus/sediment in the Figueira lake and insects in the Pousada lake (DA Luz et al., 2001). Also in the floodplain of the Upper Paraná River, the preferential items in the diet of the species differed between two open lakes connected to the Paraná River (SANTANA-PorTo \& ANDRIAN, 2009). Although H. marginatus has been classified as zooplanktivore, there was a greater consumption of insects (Diptera and Hymenoptera) in Ressaco do Manezinho and Cladocera in Ressaco do Bile. In this approach, it is important to highlight that some food resources found in the diet of species with generalist or opportunistic habits do not necessarily means a preference for that food, but may reflect the abundance of this resource in the environment or represent an accidental ingestion (BENNEMANN et al., 2000; SiLVA et al., 2012).

The predominant categories in the diet of $H$. marginatus did not substantially differ between the dry and rainy seasons within each environment analysed, indicating that, in this case, the seasonality probably did not alter the offer of food resources consumed by the species. This result differs from that observed in other studies with the same approach. For example, in the Franco stream, the items of plant origin presented higher importance in the diet of $H$. marginatus in the autumn, while in the summer and spring the items of animal origin predominated (BRANDÃO-GONÇALVES et al., 2010). According to the authors, the lower feed importance of invertebrates in the autumn may be a result of lower metabolism and, consequently, lower activity of these animals in colder periods due to their ectothermal character. In addition, the higher rainfall in the flood period may be directly related to food availability. In this period, there is an increase of organic input into the water body, which is used as substrate by autochthonous invertebrates, thus favouring an increase in the abundance of this resource to the fishes as well as in the contribution of allochthonous food items, such as terrestrial insects, fruits, and seeds (Deus \& PetrereJUNIOR, 2003; BONATO et al., 2012). It is worth noting that in the present study we did not observe representative variation in the climatic characteristics throughout the year, both in terms of water temperature and amount and intensity of rainfall, although all the collections were carried out in a period of drought which was considered one of the most intense of the last decades (MARENGO et al., 2013, 2018).

Analysing the variations in the diet of $H$. marginatus in function of the length classes, we observed, for both rivers, a notable consumption of items of animal origin in the first classes and, for the Água Suja River, an increase in the consumption of filamentous algae in the third class. During the juvenile phase, since they are in a period of increase in the body size, fishes tend to consume mainly items of animal origin, given their higher protein value (WoOtTON, 1998; MotTA \& UiEDA, 2004). Adults, in turn, are able to amplify their food spectrum (ANDRIAN et al., 2001), and can also include items of plant origin to their diet (GERKING, 1994). Inclusion of items of plant origin as animals become adults is a common pattern in the diet of omnivorous tropical fishes, like in many members of the Characidae family, such as Deuterodon langei Travassos 1957 in the Ribeirão River basin (VITULE et al., 2008) and three species of the genus Astyanax: A. aff. fasciatus Cuvier 1819 in the Pedras River, Paraná (WolfF et al., 2009), A. janeiroensis Eigenmann 1908 in the Ubatiba River, Rio de Janeiro (MAzzoni et al., 2010), and A. taeniatus Jenyns 1842 in the Mato Grosso River, also in Rio de Janeiro (MANNA et al., 2012). 
The change in the diet over the course of growth can also be seen as an adaptation of the population in order to take advantage of a wider range of available resources, enabling the species as a whole to assimilate a greater variety of foods (NIKOLSKY, 1963). Moreover, variation in the food habit of a species during its development has as advantage reducing the intraspecific competition for food or supplying the physiological, morphological or energetic needs that fish could have due to migration, sexual maturation, and/ or reproduction (BRAGA \& Braga, 1987). The fact of showing remarkable ontogenetic variation also restricts the determination of $H$. marginatus as a single trophic unit in studies that relate its food character to that of other sympatric species, without admitting the covariant size or maturation stage (VITULE et al., 2008).

Finally, the results show that, in drainages of the Upper Contas River, Hemigrammus marginatus presents an omnivorous/invertivorous food habit, including in its diet resources of different types and origins. Some items considered uncommon in the diet of the species may have been consumed because they are highly available in the environment, denoting the opportunism of $H$. marginatus. Thus, these unprecedented results are fundamental to increase the knowledge about the biology of fishes from the Upper Contas River and provide a better understanding of how the fish communities of this region are structured.

Acknowledgements. The authors thank the Fundação de Amparo à Pesquisa do Estado de São Paulo (FAPESP) for the financial support (process number 2012/58050-8320), Instituto Brasileiro do Meio Ambiente e dos Recursos Naturais Renováveis (IBAMA-SISBIO) for the collection licence granted (number 33398-1), and all those who assisted in the field work.

\section{REFERENCES}

Abelha, M. C. F.; Agostinho, A. A. \& Goulart, E. 2001. Plasticidade trófica em peixes de água doce. Acta Scientiarum, Biological Sciences 23(2):425-434.

Abell, R.; Thieme, M. L.; Revenga, C.; Bryer, M.; Kottelat, M.; Bogutskaya, N.; CoAd, B.; Mandrak, N.; Balderas, S. C.; Bussing, W.; Stiassny, M. L. J.; Skelton, P.; Allen, G. R.; UnMack, P.; NASeKa, A.; NG, R.; Sindorf, N.; Robertson, J.; Armijo, E.; Higgins, J. V.; Heibel, T. J.; WikramanaYake, E.; Olson, D.; LÓPez, H. L.; Reis, R. E.; LundberG, J. G.; Pérez, M. H. S. \& Petry, P. 2008. Freshwater ecoregions of the world: a new map of biogeographic units for freshwater biodiversity conservation. BioScience 58(5):403-414.

Afonso, A. A.; Henry, R. \& Rodella, R. C. S. M. 2000. Allochthonous matter input in two different stretches of a headstream (Itatinga, São Paulo, Brazil). Brazilian Archives of Biology and Technology 43(3):335-343.

Andrian, I. F.; Silva, H. B. R. \& Peretti, D. 2001. Dieta de Astyanax bimaculatus (Linnaeus, 1758) (Characiformes, Characidae), da área de influência do reservatório de Corumbá, estado de Goiás, Brasil. Acta Scientiarum, Biological Sciences 23(2):435-440.

Angermeier, P. L. \& J. R. Karr. 1983. Fish communities along environmental gradients in a system of tropical streams. Environmental Biology of Fishes 9(2):117-135.

AraúJo, F. G.; Andrade, C. C.; Santos, R. N.; Santos, A. F. G. \& Santos, L. N. 2005. Spatial and seasonal changes in the diet of Oligosarcus hepsetus (Characiformes, Characidae) in a Brazilian reservoir. Brazilian Journal of Biology 65(1): 1-8.

Barreto, S. B.; Nunes, L. A.; Silva, A. T.; Jucá-Chagas, R.; Diniz, D.; Sampaio, I.; Schneider, H. \& Affonso, P. R. A. M. 2016. Is
Nematocharax (Actinopterygii, Characiformes) a monotypic fish genus? Genome 59(10):851-865.

Bennemann, S. T.; Gealh, A. M.; Orsi, M. L. \& Souza, L. D. 2005. Ocorrência e ecologia trófica de quatro espécies de Astyanax (Characidae) em diferentes rios da bacia do rio Tibagi, Paraná, Brasil. Iheringia, Série Zoologia 95(3):247-254.

Bennemann, S. T.; Shibatta, O. A. \& Garavello, J. C. 2000. Peixes do rio Tibagi: uma abordagem ecológica. Londrina, Editora da UEL. 62p.

Bonato, K. O.; Delariva, R. L. \& Silva, J. C. D. 2012. Diet and trophic guilds of fish assemblages in two streams with different anthropic impacts in the northwest of Paraná, Brazil. Zoologia 29(1):27-38.

Borror, D. J.; TriPlehorn, C. A. \& Johnson, N. F. 1989. An introduction to the study of insects. 6ed. Philadelphia, Saunders College Publishing. $875 \mathrm{p}$.

Braga, F. M. S. \& Braga, M. A. A. S. 1987. Estudo do hábito alimentar de Prionotus punctatus (Bloch, 1797) (Teleostei, Triglidae), na região da ilha Anchieta, Estado de São Paulo, Brasil. Revista Brasileira de Biologia 47(1/2):31-36.

Brandão-Gonçalves, L.; de Oliveira, S. A. \& Lima-Junior, S. E. 2010. Hábitos alimentares da ictiofauna do córrego Franco, Mato Grosso do Sul, Brasil. Biota Neotropica 10(2):21-30.

BrusCa, R. C. \& BrusCa, G. J. 2007. Invertebrados. 2ed. Rio de Janeiro, Guanabara Koogan. 968p.

Buckup, P. A.; Menezes, N. A. \& Ghazzi, M. S. 2007. Catálogo das espécies de peixes de água doce do Brasil. Rio de Janeiro, Museu Nacional. 195p.

Casatti, L.; Mendes, H. F. \& Ferreira, K. M. 2003. Aquatic macrophytes as feeding site for small fishes in the Rosana Reservoir, Paranapanema River, southeastern Brazil. Brazilian Journal of Biology 63(2):213-222.

Ceneviva-Bastos, M.; Casatti, L. \& Rossa-Feres, D. C. 2010. Meso and microhabitat analysis and feeding habits of small nektonic characins (Teleostei: Characiformes) in Neotropical streams. Zoologia 27(2):191200.

Corrêa, C. E.; Hahn, N. S. \& Delariva, R. L. 2009. Extreme trophic segregation between sympatric fish species: the case of small sized body Aphyocharax in the Brazilian Pantanal. Hydrobiologia 635(1):57-65.

CRIPPA, V. E. L.; HAHN, N. S. \& FUGI, R. 2009. Food resource used by smallsized fish in macrophyte patches in ponds of the upper Paraná River floodplain. Acta Scientiarium, Biological Sciences 32(2):119-125.

Da LuZ, K. D. G.; Abujanra, F.; Agostinho, A. A. \& Gomes, L. C. 2001. Caracterização trófica da ictiofauna de três lagoas da planície aluvial do alto rio Paraná, Brasil. Acta Scientiarum, Biological Sciences 23(2):401-407.

Deus, C. D. \& Petrere-Junior, M. 2003. Seasonal diet shifts of seven fish species in an Atlantic rainforest stream in southeastern Brazil. Brazilian Journal of Biology 63(4):579-588.

Eschmeyer, W. N.; Fricke, R. \& VAn Der LaAn, R. eds. 2018. Catalog of fishes: genera, species and references (Online Version, Updated 9 January 2018). California Academy of Sciences. Available at: $<$ http://researcharchive.calacademy.org/research/ichthyology/catalog/ fishcatmain.asp > . Accessed on: 17 January 2018.

Esteves, F. A. 1988. Fundamentos de Limnologia. Rio de Janeiro, Interciência. 575p.

Esteves, K. E. \& Aranha, J. M. R. 1999. Ecologia trófica de peixes de riachos. In: Caramaschi, E. P.; Mazzoni, R. \& Peres-Neto, P. R. eds. Ecologia de peixes de riachos. Rio de Janeiro, Série Oecologia Brasiliensis. v.VI, p.157-182.

Esteves, K. E. \& LoBÓN-CerviÁ, J. 2001. Composition and trophic structure of a fish community of a clear water Atlantic rainforest stream in southeastern Brazil. Environmental Biology of Fishes 62(4):429-440.

Fiori, L. F.; Alves, G. H. Z.; HAHN, N. S. \& Benedito, E. 2016. Influence of feeding plasticity on the fitness of small Neotropical characids. Iheringia, Série Zoologia 106:e2016006.

Fragoso-Moura, E. N.; Luiz, T. F.; Coeti, R. Z. \& Peret, A. C. 2017. Trophic ecology of Hemigrammus marginatus Ellis, 1911 (Characiformes, Characidae) in a conserved tropical stream. Brazilian Journal of Biology 77(2):372-382.

Frost, W. E. \& Went, A. E. J. 1940. River Liffey Survey III. The Growth and Food of Young Salmon. Proceedings of the Royal Irish Academy. Section B: Biological, Geological, and Chemical Science 46(1940/1941):53-80. 
Gerking, S. D. 1994. Feeding ecology of fish. San Diego, Academic Press. 416p.

Gomiero, L. M. \& Braga, F. M. S. 2005. Uso do grau de preferência alimentar para a caracterização da alimentação de peixes na APA de São Pedro e Analândia. Acta Scientiarum, Biological Sciences 27(3):265-270.

Gomiero, L. M. \& Braga, F. M. S. 2008. Feeding habits of the ichthyofauna in a protected area in the state of São Paulo, southeastern Brazil. Biota Neotropica 8(1):41-47.

Grant, J. W. A. \& Noakes, D. L. G. 1987. A simple model of optimal territory size for drift feeding fishes. Canadian Journal of Zoology 65(2):270-276.

Hortal, J.; de Bello, F.; Diniz-Filho, J. A. F.; Lewinsohn, T. M.; Lobo, J. M. \& LADLE, R. J. 2015. Seven shortfalls that beset large-scale knowledge of biodiversity. Annual Review of Ecology, Evolution, and Systematics 46:523-549.

JUNCÁ, F. A.; FUNCH, L. \& ROCHA, W. 2005. Biodiversidade e conservação da Chapada Diamantina. Brasília, Ministério do Meio Ambiente. 411p.

KaWAKAMI, E. \& VAZZOLER, G. 1980. Método gráfico e estimativa de índice alimentar aplicado no estudo de alimentação de peixes. Boletim do Instituto Oceanográfico 29(2):205-207.

KNÖPPEL, H. A. 1970. Food of Central Amazonian fishes: contribution to the nutrient-ecology of Amazonian rain forest streams. Amazoniana 2(3):257-352.

Lowe-McConnell, R. H. 1999. Estudos ecológicos de comunidades de peixes tropicais. São Paulo, EDUSP. 536p.

MagurRan, A. E. 2004. Measuring biological diversity. Oxford, Blackwell Science. 256p.

Manna, L. R.; Rezende, C. F. \& Mazzoni, R. 2012. Plasticity in the diet of Astyanax taeniatus in a coastal stream from south-east Brazil. Brazilian Journal of Biology 72(4):919-928.

Marengo, J. A.; Alves, L. M.; Soares, W. R. \& Rodriguez, D. A. 2013. Two contrasting severe seasonal extremes in tropical South America in 2012: flood in Amazonia and drought in northeast Brazil. Journal of Climate 26(22):9137-9154.

Marengo, J. A.; Cunha, A. P. \& Alves, L. M. 2018. A seca de 2012-15 no semiárido do Nordeste do Brasil no contexto histórico. Climanálise 3:49-54.

Mazzoni, R.; Nerr, L. L. \& Iglesias-Rios, R. 2010. Ecologia e ontogenia da alimentação de Astyanax janeiroensis (Osteichthyes, Characidae) de um riacho costeiro do Sudeste do Brasil. Biota Neotropica 10(3):53-60.

Mise, F. T.; Fugi, R.; PAGOtTo, J. P. A. \& Goulart, E. 2013. The coexistence of endemic species of Astyanax (Teleostei: Characidae) is propitiated by ecomorphological and trophic variations. Biota Neotropica 13(3):21-28.

Motta, R. L. \& Uieda, V. S. 2004. Dieta de duas espécies de peixes do Ribeirão do Atalho, Itatinga, SP. Revista Brasileira de Zoociências 6(2):191-205.

Mugnai, R.; Nessimian, J. L. \& Baptista, D. F. 2010. Manual de identificação de macroinvertebrados aquáticos do Estado do Rio de Janeiro. Rio de Janeiro, Technical Books. 174p.

NiKoLSKY, G. V. 1963. The ecology of fishes. London, Academic Press. 352p.

Ota, R. P.; Lima, F. C. \& Pavanelli, C. S. 2015. A new species of Hemigrammus Gill, 1858 (Characiformes: Characidae) from the central and western Amazon and rio Paraná-Paraguai basins. Zootaxa 3948(2):218-232.
Pelicice, F. M. \& Agostinho, A. A. 2006. Feeding ecology of fishes associated with Egeria spp. patches in a tropical reservoir, Brazil. Ecology of Freshwater Fish 15(1):10-19.

Pusey, B. J. \& ARTHINGton, A. H. 2003. Importance of the riparian zone to the conservation and management of freshwater fish: a review. Marine and Freshwater Research 54(1):1-16.

Ruppert, E. E.; Fox, R. S. \& Barnes, R. D. 2005. Zoologia dos Invertebrados: uma abordagem funcional-evolutiva. 7ed. São Paulo, Roca. 1145p.

Russo, M. R. \& HAHN, N. S. 2006. Importance of zooplankton in the diet of a small fish in lagoons of the upper Paraná River floodplain, Brazil. Acta Limnologica Brasiliensia 18(4):357-366.

SABino, J. \& CASTRO, R. M. C. 1990. Alimentação, período de atividade e distribuição espacial dos peixes de um riacho da Floresta Atlântica (Sudeste do Brasil). Revista Brasileira de Biologia 50(1):23-36.

Santana-Porto, E. A. \& Andrian, I. F. 2009. Trophic organization the ichthyofauna of two semi-lentic environments in a flood plain on the upper Paraná River, Brazil. Acta Limnologica Brasiliensia 21(3):359366.

Silva, A. T.; Sonoda, S. L.; Affonso, P. R. A. M. \& JucÁ-Chagas, R. 2016. Hasemania piatan Zanata \& Serra 2010. Boletim da Sociedade Brasileira de Ictiologia 119:19.

Silva, D. A.; Pessoa, E. K. R.; Costa, S. A. G. L.; Chellappa, N. T. \& Chellappa, S. 2012. Ecologia alimentar de Astyanax lacustris (Osteichthyes: Characidae) na Lagoa do Piató, Assu, Rio Grande do Norte, Brasil. Biota Amazônia 2(1):74-82.

Souza, U. P.; Ferreira, F. C.; Carmo, M. A. \& Braga, F. 2015. Feeding and reproductive patterns of Astyanax intermedius in a headwater stream of Atlantic Rainforest. Anais da Academia Brasileira de Ciências 87(4):2151-2162.

SRHSH - SeCretaria dos Recursos Hídricos, Saneamento e Habitação. 1993. Plano Diretor de Recursos Hídricos, Bacia do Rio das Contas: documento síntese. Salvador, Governo do Estado da Bahia. 162p.

TERESA, F. B. \& CASATTI, L. 2010. Importância da vegetação ripária em região intensamente desmatada no sudeste do Brasil: um estudo com peixes de riacho. Pan-American Journal of Aquatic Sciences 5(3):444-453.

Uieda, V. S.; Buzzato, P. \& KiKuchi, R. M. 1997. Partilha de recursos alimentares em peixes em um riacho de serra do sudeste do Brasil. Anais da Academia Brasileira de Ciências 69(2):243-252.

Vannote, R. L.; Minshall, G. W.; Cummins, K. W.; Sedell, J. R. \& Cushing, C. E. 1980. The river continuum concept. Canadian Journal of Fisheries and Aquatic Sciences 37(1):130-137.

Vitule, J. R. S.; Braga, M. R. \& Aranha, M. R. 2008. Ontogenetic, spatial and temporal variations in the feeding ecology of Deuterodon langei Travassos, 1957 (Teleostei: Characidae) in a Neotropical stream from the Atlantic rainforest, southern Brazil. Neotropical Ichthyology 6(2):211-222.

WolfF, L. L.; Abilhoa, V.; Rios, F. S. \& Donatti, L. 2009. Spatial, seasonal and ontogenetic variation in the diet of Astyanax aff. fasciatus (Ostariophysi: Characidae) in an Atlantic Forest river, Southern Brazil. Neotropical Ichthyology 7(2):257-266.

Wootton, R. J. 1998. Ecology of teleost fishes. 2ed. Fish and Fisheries Series 24. London, Kluwer Academic Publishers. 386p. 